J政ALL JOALL (JOURNAL OF APPLIED LINGUIS'TICS ANI) LIT'RRA'TURE)

Vol. 7 No. 1, February 2022

ISSN (print): 2502-7816; ISSN (online): 2503-524X

Available online at https://ejournal.unib.ac.id/index.php/joall/article/view/16504

https://doi.org/10.33369/joall.v7i1.16504

\title{
Linguistic problems of translating Indonesian popular lyrics of cover songs into English
}

\author{
1Tira Nur Fitria \\ ${ }^{1}$ Faculty of Economics and Business, Institut Teknologi Bisnis AAS, INDONESIA \\ Jalan Slamet Riyadi No. 361, Windan, Makamhaji, Kartasura Sukoharjo, Jawa Tengah 57161
}

\begin{tabular}{|c|c|}
\hline ARTICLE INFO & ABSTRACT \\
\hline $\begin{array}{l}\text { Article history: } \\
\text { Received: June 28, } 2021 \\
\text { Revised: Sept 07, } 2021 \\
\text { Accepted: Sept 17, } 2021\end{array}$ & \multirow{5}{*}{$\begin{array}{l}\text { Translation results can be influenced by linguistic aspects. The } \\
\text { objective of this study is to investigate several kinds of linguistic } \\
\text { problems in the translation of Indonesian popular lyrics' cover- } \\
\text { songs from Indonesian into English. This study applies descriptive } \\
\text { qualitative research. This research uses the document to collect } \\
\text { data. The document used is cover songs from several popular } \\
\text { singers and bands such as Andmesh Kamaleng, Anneth, Budi } \\
\text { Doremi, Nineball, and Christian Bautista. There are seven popular } \\
\text { lyrics' cover songs that have been analyzed. The result analysis } \\
\text { shows that translation songs activities cannot be separated from } \\
\text { linguistic problems as in morphological, syntactical, phonological, } \\
\text { and semantic. Morphologically, the problem is in the difference of } \\
\text { the grammatical system related to singular and plural nouns. In } \\
\text { phonological, the problem is in the differences between Indonesian } \\
\text { and English syllables. As a result, the differences cause a different } \\
\text { pronunciation and produce a different number of syllables. } \\
\text { Syntactically, the problem is in constructing sentence elements. In } \\
\text { a sentence, both in Indonesian and English at least will need a } \\
\text { subject and a predicate orderly. Semantically, the problem is related } \\
\text { to the meaning contained in a word or sentence, but equivalence } \\
\text { may occur in translating to achieve an adequate degree of } \\
\text { equivalence. When translating a song, a translator must pay close } \\
\text { attention to the many components that contribute to the creation of } \\
\text { a full product song. These components include song lyrics or text, } \\
\text { as well as musical elements like melody and rhythm. In its } \\
\text { formulation, the song lyric is a language that is not isolated from } \\
\text { the musical principles such as the song's rhythm, melody, and } \\
\text { harmony. In song translation, the sense and facts of the source texts } \\
\text { are often changed. Therefore, the translator is faced with a choice } \\
\text { of whether or not to translate such a lyric. }\end{array}$} \\
\hline $\begin{array}{l}\text { Keywords: } \\
\text { Cover song } \\
\text { Linguistic problems } \\
\text { Lyric song } \\
\text { Translation }\end{array}$ & \\
\hline $\begin{array}{l}\text { Conflict of interest: } \\
\text { None }\end{array}$ & \\
\hline $\begin{array}{l}\text { Funding information: } \\
\text { None }\end{array}$ & \\
\hline $\begin{array}{l}\text { Correspondence: } \\
\text { Tira Nur Fitria, Faculty of } \\
\text { Economics and Business, } \\
\text { Institut Teknologi Bisnis } \\
\text { AAS, INDONESIA. } \\
\text { misstirastieaas@gmail.com }\end{array}$ & \\
\hline
\end{tabular}

CTira Nur Fitria

This is an open access article under the CC BY-SA 4.0 international license.

How to cite (APA style):

Fitria, T.N. (2022). Linguistic problems of translating Indonesian popular lyrics of cover songs into English. JOALL (Journal of Applied Linguistics and Literature), 7(1), 1-14.

https://doi.org/10.33369/joall.v7i1.16504 
Translation is used by humans to communicate ideas, thoughts, and culture to overcome the problem of having different languages (Adbellah, 2003). It should be an as clear and accurate rendition of the source text as possible (Minors, 2012). Translation results can be affected by the mastery of linguistic aspects. The higher a person's understanding and mastery of linguistic aspects, the better the resulting translation work (Rachmawati, 2017). The translator works on linguistic forms: "... the translator does not share the sense of linguistic forms but, he interprets." (Stiegelbauer, 2016).

Translation and linguistics are two things that cannot be separated (Sriyono, 2018). The concept of translation involves shifting linguistic units both at the word level and different discourses so that the translation results can be read and interpreted properly. Although it is not the only one, the linguistic aspect is important to observe in carrying out translation activities and studies (Fitria, 2020a, 2020b). Therefore, there is an assumption that the linguistic element is the foundation of translation activities and studies because of the meaning and form of the language that is transferred. Another assumption is that translation in practice and its studies require linguistic theories as a means of uncovering all difficulties and problems in translation.

However, in general, the linguistic aspect has an impact on the field of translation both in translation theory and practice. Newmark (1998) states that an adequate understanding of linguistic aspects is an important part of the translator. Several aspects of language, starting from morphology, syntax, and even semantics, are linguistic domains that can be a support in translation, both in terms of study and practice. Sufficient knowledge of linguistic aspects can reduce the ambiguity of meaning in ST into TT to maximize the results of adequate translation. Therefore, the search for solutions to translation problems cannot be avoided from linguistic problems with both functional and structural paradigms.

Furthermore, linguistics and other branches of linguistics, be it morphology, phonology, semantics, sociolinguistics, or other branches, can "mix" with translation. Therefore, translation and linguistics are inseparable fields. Linguistics contributes to studying and even researching the area of translation, while translation itself intersects directly with linguistics at both the theoretical and practical levels. The relationship between the two fields illustrates that translation and linguistics can be studied separately or together.

Translating is one of those difficult processes. Differences such as structure, meaning, and culture can be difficult factors in translation. From these differences, a translator needs a certain strategy in translating a text. Meanwhile, the strategies used are very diverse, depending on the type of text. Translating song lyrics, like translating poetry, requires a special strategy 
that includes the transfer of form and meaning from the source language (SL) into the target language (TL). When translating a song, a translator must pay close attention to any components that contribute to the creation of a full product song. These components include song lyrics or text, as well as musical elements like melody and rhythm. In its formulation, song lyric is a language that is not isolated from the musical principles such as the song's rhythm, melody, and harmony (Suharto \& Subroto, 2014). To produce inter-semiotic translations that are functional and moveable, the translator must pay attention to all the elements that exist in the phenomenon to be translated. Therefore, the translator must keep in mind the complications of the many semiotic elements interplaying with words.

Harsono (2020) states that song translation refers to the rule that the translation results must be able to be sung, which is known as "singability". When devising a singable song, one has a very clear goal in mind: to create a text that a vocalist may perform in front of an audience (Low, 2016). From a functional standpoint, the notion of "singability" in song translation explains the strategic decisions taken by the translator or lyricist in translating the song. This word refers to a text's musical-verbal compatibility with music, as well as the fact that this musico-verbal union exists can consist of several layers-prosodic, poetic, and semantic-reflexive. Franzon (2014) states that Based on the assumption that a song has three properties (music, lyrics, and performance) and music has three (melody, harmony, and musical taste), a song translator may have five options in theory: not translating lyrics, translating lyrics, writing fresh lyrics, adjusting music to translation, and adapting translation to music may all be integrated in practice, regardless of the music.

The translation of song lyrics is a relatively new field of linguistic research (Gritsenko \& Aleshinskaya, 2016). Several linguistic problems are faced in translating songs especially songs with Indonesian to English lyrics (Suharto, 2006). Translation into Indonesian can still be compromised, especially in terms of the rhythm of the song and the rhythm of the language because it is in Indonesian. But it will appear when the accented song does not match the accent language. Sometimes the translators of the translated songs do not pay attention to this problem. Here are some of the problems that may be encountered in translating songs. Gorlée (2005) states that in song translation, the sense and facts of the source texts are also often changed. The translator is faced with several choices, the first being whether or not to translate such a lyric at all (Apter \& Herman, 2016). The translation of songs has received little attention in translation studies until lately; one explanation for this may be a lack of clarity about the professional identity of those who translate songs (Harsono, 2020). 
Several previous studies have been conducted related to the linguistic problem. The first study was conducted by Alfadly \& AldeibaniFull (2013). This research aims to empirically investigate certain linguistic issues in English-Arabic translations and vice versa and to find concrete examples of the areas that raise real problems for Hadramout University English Language Undergraduates. The second study was conducted by Okere et al. (2018) The goal of this paper was to figure out the reasons behind the linguistic difficulties when translating poetry from the source text in English to the target text in Kiswahili. The third study was conducted by Madkour (2016) This case study thesis was focused on a generic exploration of the translation issues encountered in literary translation by graduate students. The fourth study was conducted by Guerra (2012) to discover the key methods and techniques for translation to address challenges in the translation of cultures.

Based on several previous studies above, do not only have similarities but also differences with this study. In a similar aspect, several previous studies and this study focus on the linguistic problems in translation. In a different aspect, several previous studies and this study have the different objects of the study analyzed. The first study concerns English-Arabic and Arabic-English translation. The second study concerns poetry translation from English into Kiswahili. The third study concerns literary translation from Indonesian into English. The fourth study concerns cultural translation. The translation of lyric songs has received little attention in translation studies; one explanation for this may be a lack of clarity about the professional identity of those who translate songs. But, this research is interesting to be discussed. This study idem translating Indonesian into English lyrics from Indonesian popular cover songs. Therefore, the objective of this study is to investigate several linguistic problems in the translation of Indonesian popular lyrics' cover songs from Indonesian into English.

\section{METHOD}

This research employs descriptive qualitative research. The purpose of qualitative research is to conduct a systematic study of a case or cases and to give a description of the research object (Boudah, 2010, p. 127). So, this research describes the phenomenon (case) related to the linguistic problems which may occur in the translation of the Indonesian popular cover songs.

Collecting data in this research is done by using documents. According to Merriam (2009, p. 139), a document is the umbrella term that refers to a wide range of visual, written, physical material, or even digital material related to the research. The document here is in the form of song lyrics from the popular cover song. The cover song refers to the recording of a song generally identified with a singer or musical group by another singer or group (Edmondson, 2013, p. 310). This research limits this research and focuses on 
popular cover songs in Indonesia. The research only uses several popular cover songs in Indonesia which are covered by non-Indonesian singers. Indonesian singers and Band groups are from Andmesh Kamaleng, Budi Doremi, and Nineball.

Analyzing data in this research by using several steps, such as the researcher moves among these activities during data collection and then shuttles among reduction, displaying data, and conclusion drawing/verification (Helms, 2020). In data analysis, the researcher chooses which data is relevant to be used to strengthen the research report. Furthermore, the researcher displays the data in the form of a narrative, chart, flow chart, and others. Furthermore, the researchers draw conclusions that include important information in the study in general.

\section{FINDINGS}

\section{Morphology}

In the Indonesian language song lyric, which is covered and translated into English lyrics, it is found that there is a morphological problem, as follow:

\begin{tabular}{ll} 
1st Example & \\
\hline English & $\begin{array}{l}\text { When I am by myself | Looking at photos and videos that we took | } \\
\text { I've been keeping them for so long | And with my broken heart | I see } \\
\text { all the pictures of myself (English version, Emma Heesters) }\end{array}$ \\
\hline Indonesian & $\begin{array}{l}\text { Saat ku sendiri, ku lihat foto dan video | Bersamamu yang telah lama } \\
\text { ku simpan | Hancur hati ini melihat semua gambar diri (Hanya Rindu, } \\
\text { Andmesh Kamaleng) }\end{array}$ \\
\hline
\end{tabular}

\begin{tabular}{ll} 
2nd $^{\text {Example }}$ \\
\hline English & $\begin{array}{l}\text { I will always look forward to your return | But till then I know the } \\
\text { memories are all that's left (English version, Emma Heesters) }\end{array}$ \\
\hline Indonesian & $\begin{array}{l}\text { Ku menanti hadirmu 'tuk kembali | Hanya kenangan yang tersisa di } \\
\text { sini (Mungkin Hari Ini Esok Atau Nanti, Anneth) }\end{array}$ \\
\hline 3rd Example $^{\text {rd }}$ & $\begin{array}{l}\text { And let me show you an extraordinary world | don't have flowers | } \\
\text { don't have gold | but I just want you to know | I'll give you every } \\
\text { feeling your dreaming of | so you'll know incredible love (English } \\
\text { version, Emma Heesters) }\end{array}$ \\
\hline English & $\begin{array}{l}\text { Tapi cintaku padamu luar biasa | Aku tak punya bunga | Aku tak } \\
\text { punya harta | Yang kupunya hanyalah hati yang setia (Cinta Luar Biasa, } \\
\text { Andmesh) }\end{array}$ \\
\hline
\end{tabular}

The table above shows a morphological problem from several morphemes in Indonesian into English song lyrics especially in changing singular into plural form. This is called an inflectional morpheme. This morpheme does not cause changes in word class and word meaning, but these 
morphemes only affect the number (plurality) from Indonesian into English words in a lyric song. In the first lyric, the lexical morphemes 'foto', 'video', and 'gambar' as a singular form are translated into 'photos', 'videos', and 'pictures' to be a plural form. In the second and third lyrics also, the morphemes 'bunga' and 'kenangan' as singular forms are translated into 'flowers' and 'memories' to be a plural form. The plural form is signed by adding an apostrophe ' $s$ ' in the word. The use of an apostrophe ' $s$ ' is to end countable nouns. If we want to say that an object is plural or the number is more than one, then add an apostrophe ' $s$ ' to the end of the noun. The change of singular form in the source text (Indonesian) into plural in the target text (English).

\begin{tabular}{ll} 
4th $^{\text {th }}$ Example \\
\hline English & $\begin{array}{l}\text { I need you here with me | You'd brush away this loneliness from me } \\
\text { (English version, Christian Bautista) }\end{array}$ \\
\hline Indonesian & $\begin{array}{l}\text { Dan takkan mungkin ada yang lain di sisi | 'Ku ingin kau di sini } \\
\text { tepiskan sepiku bersamamu (Hingga akhir waktu, Nineball) }\end{array}$ \\
\hline \begin{tabular}{l}
$\mathbf{5}^{\text {th }}$ Example \\
\hline English
\end{tabular} & $\begin{array}{l}\text { Let me write a perfect melody | Your name in it will sound perfectly | } \\
\text { I'll listen to all your stories | And we will laugh and we will cry (English } \\
\text { version, Emma Heesters) }\end{array}$ \\
\hline Indonesian & $\begin{array}{l}\text { Izinkan kulukis senja | Mengukir namamu di sana | Mendengar kamu } \\
\text { bercerita | Menangis, tertawa (Melukis Senja, Budi Doremi) }\end{array}$ \\
\hline
\end{tabular}

The table above shows there is a morphological problem from the morpheme in Indonesian into English song lyrics especially in changing word class. This is called a derivational morpheme. In the fourth lyric, the lexical morpheme 'sepi' as an adjective is translated into 'loneliness' to be a noun. The word 'loneliness' is formed by 'lonely' then added by suffix -ness to be noun' In the fifth lyric, the lexical morpheme 'bercerita' as a verb is translated into 'stories' to be a noun. The shift in word class that occurs from the adjective into the noun word class will also result in a shift in the function and meaning of a word.

\section{Syntactic}

In the Indonesian language song lyric, which is covered and translated into English lyrics, it is found that there is a syntactical problem, as follow:

$1^{\text {st }}$ example

Indonesian Segala cara telah kucoba (Hanya Rindu, Andmesh)

English I tried everything Just Missing You (English version, Emma Heesters)




\section{$2^{\text {nd }}$ Example}

\begin{tabular}{ll}
\hline English & Aku tak punya bunga, Aku tak punya harta (Cinta luar Biasa, Andmesh) \\
\hline Indonesian & Don't have flowers, don't have gold (English version, Emma Heesters) \\
\hline
\end{tabular}

The table above shows there is a syntactical problem in Indonesian into English song lyrics especially in ordering the sentences. In Indonesian lyric, it is written "segala cara telah kucoba". This sentence is not written orderly with Subject + Predicate. But, in its English lyric, it is translated into "I tried everything". This sentence is written orderly with Subject + Predicate. In the second example, In Indonesian lyric, it is written: "Aku tak punya bunga, Aku tak punya harta". This sentence is written orderly with Subject + Predicate + Object. But, in its English lyric, it is translated into "Don't have flowers, Don't have gold". This sentence is not written orderly with Subject + Predicate. This English Translation is the missing subject of the sentence.

\section{Phonology}

In the Indonesian language song lyric, which is covered and translated into English lyrics, it is found that there is a phonological problem, as follow:

\section{$1^{\text {st }}$ Example}

Indonesian Hing - ga - a - khir - wak - tu (Hingga Akhir Waktu, Nineball)

English Till - the - end - of - time (English version, Christian Bautista)

The example above shows there is a phonological problem in Indonesian into an English song lyric, especially in syllables. In Indonesian lyric is written "Till the end of time" which consists of five syllables. While, in this English translation, it is written: "Hingga akhir waktu" which consists of six syllables. A syllable is the smallest unit of pronunciation. The syllable decapitation in English is different from that in Indonesian, so it causes a different pronunciation. Besides that, it can also produce a different number of syllables.

\section{Semantics}

In the Indonesian language song lyric which is covered and translated into English lyrics, it is found that there is a phonological problem, as follow:

\section{$2^{\text {nd }}$ Example}

Indonesian $\quad$ Izinkan kulukis senja (Melukis Senja, Budi Doremi)

English Let me write a perfect melody (English version, Emma Heesters)

The table above shows there is a semantic problem in Indonesian into English song lyric especially in translating the word. In Indonesian lyric is written "senja". The word "senja" here means the beauty of nature as a barrier 
between day and night or part of the time in the day or a half-dark state after sunset. But in English lyric translation is translated into "perfect melody" which refers to the song or singing.

\section{DISCUSSION}

Translation studies always involve elements of linguistic knowledge so that translation is one of the applications in linguistics. All parts of linguistics such as syntax, semantics, pragmatics, surface and deep structures, maxims, and others are always involved in translation. Before someone translates, the translator must first understand the intrinsic elements in linguistics. Based on the analysis, several linguistic problems can occur in the translation of songs especially cover songs with Indonesian to English lyrics, they are as follows:

First, in morphology. Morphology is the study of the form (Toussaint, 2014). This means morphology is concerned with word formation (Galani et al., 2011, p. 1). According to Fabregas \& Scalise (2012, p. 1), morphology examines the grammatical characteristics of words and how words are linked to one other in a language. Morphology is the study of form or forms (Aronoff \& Fudeman, 2011). It is supported by Hamawand (2011) that morphology is the study of the form-meaning relationships between lexical units and their arrangement in forming words, phrases, clauses, or sentences. Morphology as part of linguistic knowledge is important for translators to master. Besides, translation studies can also be examined with cases of morphology and how words are formed between ST and TT. The different constructs of morphology between the source language and the target language make considerations in determining the right type of equivalent between ST and TT. In English, the morpheme affixation system is not the same as in Indonesian. Morphological processes in English and Indonesian tend to be different and can have an impact on the meaning and process of word-formation between the source language and the target language. Furthermore, the formation and how words are formed need to be paid attention and paid close attention to in translating. This is because word formation has an impact on translation when interpreting or understanding the word.

In the example in findings above, morphological problems are in inflection. Fabregas \& Scalise (2012, p. 69) state that inflection is unable to change the grammatical category of the base. An inflectional morpheme (inflectional morpheme or inflectional) is a morpheme that does not cause changes in word class and word meaning. This morpheme only affects the number (plurality) and form of time (tenses). The language difficulty in translation is also the difference in the grammatical system related to singular and plural nouns. The grammatical system of singular and plural noun forms in English is different from Indonesian. English has multiple indicators. 
Second, in syntactical. Syntactic (grammar) aspects are an inevitable part of translation. This is related to the equivalent meaning and grammar that should be achieved through translation. The lexical elements in translation have an adequate equivalent between the Source Text (ST) and the Target Text (TT). An adequate understanding of syntax can affect the results of a quality translation. Mastery of syntactic science is an element that dominates translation activities. The syntax is related to how words can be combined in the form of phrases and sentences, to determine the principles of how words can be combined or cannot be combined in determining to mean, (Radford, 2003: 2). in translation. The difference in structure in a sentence between ST and ST makes the syntactic aspect one of the determinants of how the meaning of a sentence or clause is determined for its equivalence. In addition, the grammatical pattern in ST can also determine how translation should be done. At the level of simple sentences, it is possible to translate simply and easily.

At the syntactic level, in the translation of linguistic units that form phrases, clauses, or sentences, it is necessary to pay close attention to achieving adequate equivalences, especially grammatical equivalents that lead to textual equivalents. One of the problems in translation, especially in terms of syntax, is how the translator pays attention to aspects of the sentence that have a function grammatical and function (Armstrong, 20015: 111). Thus, translation requires an adequate understanding of syntactic elements which include aspects of phrases, clauses, and sentences. In English and Indonesian translation, the translation of phrases becomes a complicated part to be translated, especially concerning the translation of noun phrases. However, in translating English into Indonesian, translating noun phrases is not the only problem. becomes a difficulty in itself.

In the example in the findings above, in making a sentence, both in Indonesian and English, we at least will need a subject and a predicate. The subject is one of the important elements in the sentence. A subject can be defined with who or what. The subject is who or what does an activity/action in the sentence. Subject in a sentence can be a noun, a noun phrase, or a pronoun. A predicate is a phrase that provides information about the activities/actions/actions performed by the subject in a sentence. The predicate contains a verb that talks about the activities/actions/actions performed. The predicate also provides information about the relationship between the subject and the activity/action performed in a sentence. In writing sentences in good and correct Indonesian or English, we must know the elements that are usually used in a sentence, at least sequentially from the subject and followed by the predicate.

Third, in phonology. Phonology relates to the implicit knowledge of language sound structure...(Bod et al., 2003). Kreidler (2001, p. 76) states that 
the syllable plays an important role as a prosodic constituent in phonology. Syllables are pieces/decapitations in words. A syllable in pronunciation consists of a vowel sound. This syllable can coincide with consonants or not. Attention to the number of syllables is very important in songwriting and song translation. The translator may have translated the words of each line and the meaning is already appropriate, but does it match the number of syllables that make up the rhythm of the song? It could be said that it is impossible. It is very difficult to do because not all word equivalents between the two words involved have the same number of syllables. What can be done is the possibility of a shift. In the science of translation, shifts are very common. The problem is that this shift will cause the stress of the word to move.

In the example in the tables above, in Indonesian, syllables are the smallest units of pronunciation. The syllable decapitation in English is slightly different from Indonesian, so it causes a different pronunciation. In addition, it can also produce a different number of syllables. Some of the examples in the findings above should open our minds that the syllable aspect in English needs to be learned. This is because the style is different from the syllables in Indonesian. A syllable is the smallest unit of pronunciation. The syllable decapitation in English is different from that in Indonesian, so it causes a different pronunciation. Besides that, it can also produce a different number of syllables.

Fourth, in semantic. Meaningfulness is one of the important things in translation. Meanings can be traced from the semantic system used from lexical units of language. A broad and good understanding of the concept of semantics can be a means for how a linguistic lexicon from ST can be translated adequately. Semantic aspects are closely related to the concept of meaning in translation. In translation, the concept of meaning becomes important to understand as one part that needs to be considered well including lexical meaning, conceptual meaning, and other meanings. A deeper understanding is needed to become a reference in determining the equivalence between Tsu and Tsa. The semantic dimension is important to note. It is because of translating the elements of meaning to be transferred well. The dimension of meaning in translation does not only create problems of connotation and denotation of the meaning being translated. The lexical unit should be understood from various perspectives of the dimensions of meaning to obtain appropriate concepts and terms between ST and TT. The following describes the meanings of carrying and other types of lexical units.

Semantic inequality becomes an inseparable part if the semantic dimension is not observed in the translation of linguistic units. Semantic meaning can be a part of concern in translation. semantic is not only related to the meaning contained in a word or sentence, but equivalence may occur 
in translating to achieve an adequate degree of equivalence. Translation with a semantic aspect illustrates that to determine the type of equivalence, the semantic element is important. In translation, the semantic aspect provides a direction on how lexical equivalents can have adequate equivalences. Therefore, in translating the source language into the target language, the form may be changed but the meaning must be preserved.

In the examples above, Indonesian lyric is translated differently into English. semantic equivalence is the most important thing that must be achieved in translation. The semantic aspect has an impact on the lexical equivalence that must be achieved in translating. Semantics as part of the study of meaning, the relationship between the internet in translation needs to be considered carefully. Meaning is an inseparable part of translation. Several types of meaning can provide direction and determine what meaning will be the basis of the translation. In translating the lexical meaning, it can provide different meanings between ST and TT. Furthermore, one lexical meaning can have more than one concept or meaning in different languages. Thus, this is supported by what Larson (1997: 109) stated that the character of one word which has one lexical meaning has several meanings in mind. In translation, the lexical unit illustrates that to determine the meaning, it is necessary to consider the suitability of the meaning between ST and TT.

Translation and linguistics are two things that cannot be separated. The concepts of translation involve a single linguistic unit at the word level up to different discourses so that the results of the translation can be read, understood, and interpreted properly. The linguistic aspect is important to observe in conducting translation activities and studies. Therefore, there is an assumption that the linguistic element is the foundation of the translator's activities and studies because the meaning and form of the language are transferred. Another statement is that translation in practice and study requires linguistic theories as a means to unravel all difficulties and problems in translation. Therefore, we can see the relationship between translation and linguistics and what are the methods, stages of the translation itself.

\section{CONCLUSION}

Several linguistic problems occur in the translation of songs especially songs with Indonesian to English lyrics such as morphology, syntax, phonology, and semantic. The morphological problem occurs in several morphemes in Indonesian into English song lyrics especially in changing singular into plural form and changing word-class such as in the cover song. The syntactical problem occurs in several morphemes in Indonesian into English song lyrics, especially in misordering subject-verb agreement. The phonological problem occurs in several morphemes in Indonesian into English song lyrics especially in the syllable decapitation in English and Indonesian, so it causes a different 
pronunciation. While in semantic problem occurs in several morphemes in Indonesian into English song lyric especially in the concept of meaning in translation.

Translation activities cannot be separated from linguistic problems. Understanding various elements and concepts in linguistics can describe how translation problems can be resolved both for empirical studies and for practice. Sufficient knowledge of linguistic aspects can support understanding translation in all its aspects, both at the micro-linguistic level to the macro-linguistic level. However, the linguistic aspect is not the only area that is directly related to translation, several other aspects also need good attention, including cultural issues which can be related to translators, source texts, target texts, or studies of culture and translation.

The translation is no easy job: a difficult balance between language and culture is continually faced by translators. They must, on the one hand, strive to remain true to the vocabulary used in the original text and ensure that their translated text retains the same importance and importance as the original in its context in the target culture. When interpreting foreign-language songs, striking this balance is especially difficult. To be singable in another language, the songs must surrender sincerity in context, and vice versa.

\section{ACKNOWLEDGMENTS}

I would like to thank the Institute of Technology Business AAS Indonesia for allowing me to do research. I also thank the journal editors and anonymous reviewers who have given me feedback on my piece of writing.

\section{REFERENCES}

Adbellah, A. S. (2003). The problem of translating English LinguisticTerminology into Arabic. Camling Proceeding, 7.

Alfadly, H. O., \& AldeibaniFull, A. A. (2013). An Analysis of some Linguistic

Problems in Translation between Arabic and English Faced by Yemeni English Majors at Hadramout University. 3(1), 12.

Apter, R., \& Herman, M. (2016). Translating For Singing: The Theory, Art and Craft of Translating Lyrics. Bloomsbury Publishing.

Aronoff, M., \& Fudeman, K. (2011). What is Morphology? John Wiley \& Sons. Bod, R., Hay, J., \& Jannedy, S. (2003). Probabilistic Linguistics. MIT Press.

Boudah, D. J. (2010). Conducting Educational Research: Guide to Completing a Major Project. SAGE.

Edmondson, J. (2013). Music in American Life: An Encyclopedia of the Songs, Styles, Stars, and Stories that Shaped our Culture: ABC-CLIO.

Fabregas, A., \& Scalise, S. (2012). Morphology: From Data to Theories. Edinburgh University Press. 
Fitria, T. N. (2020a). Translation Procedure of English to Indonesian Subtitle "English Vinglish" Movie. Rainbow : Journal of Literature, Linguistics and Culture Studies, 9(1), 40-48. https://doi.org/10.15294/rainbow.v9i1.38132

Fitria, T. N. (2020b). Translation Shift in English into Indonesian Subtitle of Guzaarish Movie. Journal of Language and Literature, 20(2), 307. https:// doi.org/10.24071/joll.v20i2.2601

Franzon, J. (2014). Choices in Song Translation. The Translator, 14, 373-399. https:/ / doi.org/10.1080/13556509.2008.10799263

Galani, A., Hicks, G., \& Tsoulas, G. (2011). Morphology and its Interfaces. John Benjamins Publishing.

Gorlée, D. L. (2005). Song and Significance: Virtues and Vices of Vocal Translation. Rodopi.

Gritsenko, E., \& Aleshinskaya, E. (2016). Translation of Song Lyrics as Structure-related Expressive Device. Procedia - Social and Behavioral Sciences, 231, 165-172. https:/ / doi.org/10.1016/j.sbspro.2016.09.087

Guerra, A. F. (2012). Translating culture: Problems, strategies and practical realities. Journal of Literature, Culture and Literary Translation, 1.3. https:// doi.org/10.15291/sic/1.3.1t.1

Hamawand, Z. (2011). Morphology in English: Word Formation in Cognitive Grammar. A\&C Black.

Harsono, S. (2020). Penerjemahan Lirik Lagu untuk Pembelajaran Bahasa Inggris. Harmoni, 4(1), 6.

Helms, R. M. (2020). Inhabiting the Borders: Foreign Language Faculty in American Colleges and Universities. Routledge.

Kreidler, C. W. (2001). Phonology: Critical Concepts in Linguistics. Taylor \& Francis.

Low, P. (2016). Translating Song: Lyrics and Texts. Taylor \& Francis.

Madkour, M. (2016). Linguistic Levels of Translation: A Generic Exploration of Translation Difficulties in Literary Textual Corpus. International Journal of Applied Linguistics and English Literature, 5, 90-98. https:// doi.org/10.7575/aiac.ijalel.v.5n.6p.99

Merriam, S. B. (2009). Qualitative Research: A Guide to Design and Implementation. John Wiley \& Sons.

Minors, H. J. (2012). Music, Text and Translation. A\&amp;C Black.

Newmark, P. (1998). More Paragraphs on Translation. Multilingual Matters.

Okere, B. A., Onyango, J. O., \& Chai, F. (2018). Linguistic Challenges in Translating Song of Lawino From English To Kiswahili. International Journal of Linguistics, Literature and Translation, 6.

Rachmawati, R. (2017). Aspek Linguistik dan Keberterimaan dalam Penerjemahan. Madah: Jurnal Bahasa dan Sastra, 5(1), 91. https://doi.org/10.31503/madah.v5i1.527 
Sriyono, S. (2018). Aspek Linguistik Dalam Penerjemahan. Prosodi, 12(2), 273-281. https:// doi.org/10.21107/ prosodi.v12i2.4556

Stiegelbauer, L. (2016). Translation Problems and Difficulties in Applied Translation Processes. Revista de Stiinta Si Cultura, Volumul XIINumarul 3 (46) 2016 Studii de Stiinta si Cultura-Volumul XII 2016Numarul 3 (46), 51-58.

Suharto, S. (2006). Permasalahan Musikal dan Lingual dalam Penerjemahan Lirik Lagu. Harmonia: Journal of Arts Research and Education, 7(2), Article 2. https://journal.unnes.ac.id/nju/index.php/harmonia/article/view/ 756

Suharto, S., \& Subroto, E. (2014). The Equivalence of Translated Songs Lyrics and their Effects - The Case of Translated Ecclesial Songs. Harmonia: Journal of Arts Research and Education, 14(2), 131. https:// doi.org/10.15294/harmonia.v14i2.3294

Toussaint, G. T. (2014). Computational Morphology: A Computational Geometric Approach to the Analysis of Form. Elsevier.

\section{THE AUTHOR}

Tira Nur Fitria is an English lecturer at Institut Teknologi Bisnis AAS, Indonesia. She pursued her undergraduate degree at the English Education Study Programme State Islamic University of Raden Mas Said Surakarta in 2013 and Master of Language Studies at Muhammadiyah University of Surakarta (UMS) in 2015. Not only does she teach English, but she also serves as researcher, freelance translator, content creator, and reviewer of accredited and unaccredited national journals. 